\title{
Rapid lipid profiling of bacteria by online MALDI-TOF mass spectrometry
}

\author{
Xi Shu, Yueyan Li, Miao Liang, Bo Yang, Changgeng Liu, Youfeng Wang, Jinian Shu* \\ Research Center for Eco-Environmental Sciences, Chinese Academy of Sciences, Beijing 100085, China
}

\section{A R T I C L E I N F O}

\section{Article history:}

Received 10 March 2012

Received in revised form 30 May 2012

Accepted 30 May 2012

Available online 9 June 2012

\section{Keywords:}

Lipid

Online MALDI

Bacterium

Escherichia coli

Salmonella

Bacillus subtilis

\begin{abstract}
A B S T R A C T
The rapid identification of bacteria is of increasing interest in food, biosafety, and clinical analysis. In this paper, we report a technique for rapid lipid profiling of bacteria by online droplet-deposited MALDI mass spectrometry. In the experiment, lipids in bacterial cells (Escherichia coli, Salmonella, and Bacillus subtilis) are extracted with the mixture of chloroform/methanol via ultrasonication. The extracts are nebulized into suspended droplets and then instantly analyzed with an online droplet-deposited MALDI-TOF mass spectrometer. The lipid profiles of the three bacteria cultured in nutrient broth and LB (Lysogeny Broth) medium are obtained. The lipids phosphatidylethanolamine (PE), diglycosyl diacylglycerol (DGDG), and phosphatidylglycerol (PG) are observed in the MALDI-TOF mass spectra. The MALDI-TOF mass spectrum of each bacterial extract shows a characteristic profile. The experimental results demonstrate that the present technique is capable of conducting rapid lipid analysis and has the potential for rapid bioaerosol detection.
\end{abstract}

(c) 2012 Elsevier B.V. All rights reserved.

\section{Introduction}

Lipids are important constituents of all living organisms [1]. Besides served as energy sources, lipids act as signaling molecules, neurotransmitters, and precursors for second messengers in the regulation of cellular functions (such as proliferation, apoptosis, inflammation, metabolism, and immunity), as well as in direct DNA modulation $[2,3]$. The study of the lipids can improve further understanding of diseases such as cancer, arthritis, inflammation, diabetes, immune function, and neurodegenerative disorders. Lipidomics as a new "omic" field plays an essential role in defining the biochemical mechanisms of lipid-related disease processes through identifying alterations in cellular lipid metabolism, trafficking, and homeostasis [4-6]. This field has received much attention and been driven in good measure by advances in mass spectrometry [2,7-9].

The most used techniques for lipid analyses are based on gas chromatography/mass spectrometry (GC/MS) analysis of fatty acid methyl esters (FAMEs) of lipids extracted from cell membranes or pyrolysis GC/MS analysis of whole bacterial cells [10-13]. To overcome the time-consuming sample pretreatment (hydrolysis and derivatization) and complicated data interpretation of pyrolysis $\mathrm{GC} / \mathrm{MS}$, the techniques based on electrospray ionization (ESI) and

\footnotetext{
* Corresponding author. Tel.: +86 0106284 9508; fax: +86 01062923563.

E-mail address: jshu@rcees.ac.cn (J. Shu).
}

MALDI have been applied to analyze lipid extracts or lipids in whole cell bacteria [14-17].

Many techniques and methods have been used to introduce the liquid sample into MALDI-TOF mass spectrometers to achieve online MALDI analysis [18-22]. Li and Wang used a capillary to deliver the liquid sample directly to the MALDI sample probe $[18,19]$. Spraying has been a traditional method to introduce the liquid sample into the vacuum chamber of analytical instruments [23]. Murray and coworkers first used the aerosol MALDI to analyze the liquid sample $[24,25]$. In that method, nitrogen gas sprays the liquid into a vacuum chamber and thereafter the droplets are dried into particles by passing a heated tube. The dried particles flying through the detection region of aerosol-MALDI MS are intercepted by desorption/ionization laser [24,25]. The similar techniques were also used by many other research groups to achieve online MALDI analysis [26-29].

In this work, we employ the technique of online dropletdeposited MALDI mass spectrometry to profile bacterial lipids. The lipids extracted from bacterial cells (Escherichia coli, Salmonella, and Bacillus subtilis) are nebulized into suspended droplets. The droplets are deposited continuously on the target plate and analyzed synchronously with an online dropletdeposited MALDI-TOF mass spectrometer [30]. The cumbersome process of preparing analyte/matrix layers on the target is avoided in the experiment. The total sample preparation time is shortened compared with the traditional MALDI analysis. 


\section{Material and methods}

\subsection{Reagents and chemicals}

2,4-Dihydroxybenzoic acid (2,4-DHB) and 2,5dihydroxybenzoic acid (2,5-DHB) are purchased from Sigma. Trifluoroacetic acid, chloroform, dichloromethane, methanol, alcohol, isopropanol, acetonitrile, sodium chloride $(\mathrm{NaCl})$, potassium chloride $(\mathrm{KCl})$, peptone, and the beef extract are purchased from Beijing Shiji (Beijing, China). Deionized water is supplied by the RCEES supporting laboratory. All of the chemicals are of analytical grade.

\subsection{Bacterial culture and preparation}

E. coli, Salmonella, and B. subtilis strains used in the experiment are provided by State Key Laboratory of Environmental Aquatic Chemistry of China. The bacteria are cultured in nutrient broth and common LB (Lysogeny Broth). The nutrient broth medium is prepared by dissolving beef extract ( $3 \mathrm{~g}), \mathrm{NaCl}(5 \mathrm{~g})$, and peptone ( $10 \mathrm{~g}$ ) in deionized water $(1 \mathrm{~L})$ with a final $\mathrm{pH}$ of 7.0. And the $\mathrm{LB}$ medium is prepared by dissolving yeast extract $(5 \mathrm{~g}), \mathrm{NaCl}(10 \mathrm{~g})$, and peptone $(10 \mathrm{~g})$ in deionized water $(1 \mathrm{~L})$ with a final $\mathrm{pH}$ of 7.0 . The bacteria are inoculated in $500 \mathrm{~mL}$ of culture medium and grown aerobically at $37^{\circ} \mathrm{C}$ in a shaker incubator shaking at $220 \mathrm{rpm}$ for $24 \mathrm{~h}$.

After incubation, the bacterial cells are harvested by centrifugation at $9000 \mathrm{rpm}$ for $3 \mathrm{~min}$ at room temperature. The deposited bacteria are washed and centrifuged three times with deionized water for desalting. The harvested bacteria are resuspended in $3 \mathrm{~mL}$ water and inactivated by addition of $7 \mathrm{~mL}$ ethanol. The samples are stored at $4{ }^{\circ} \mathrm{C}$ until further analysis. The numbers of cells per volume are counted under a light microscope. Unless otherwise specified, the corresponding cell density in the final extract is approximately $5.8 \times 10^{7}$ cells $/ \mathrm{mL}$.

\subsection{MALDI-TOF MS analysis}

Lipids from bacterial pellets are extracted with chloroform/methanol $(2.5 \mathrm{~mL} / 2.5 \mathrm{~mL})$ via $5 \mathrm{~min}$ ultrasonication under room temperature, otherwise specified. The solid materials in the mixtures are removed by centrifugation at $9000 \mathrm{rpm}$ for $3 \mathrm{~min}$. A $0.5 \mathrm{~mL}$ aliquot of the extract is added with $4.5 \mathrm{~mL}$ of the matrix solution $(20 \mathrm{mM})$ for MALDI analysis. Then, the analyte/matrixcontained solution is nebulized into suspended droplets with a traditional jet nebulizer and the droplets are instantly analyzed with an online droplet-deposited MALDI-TOF mass spectrometer. The consumption rate of analyte/matrix-contained solution is $\sim 0.2 \mathrm{~mL} / \mathrm{min}$. Fig. 1 shows the overall workflow of the experiment. In order to assess the repeatability/reproducibility of the method, each sample is at least prepared in triplicate. And the same experiments are repeated in several days later.

The design of the laboratory-built online droplet-deposited MALDI-TOF mass spectrometer was described in detail elsewhere [30]. The suspended droplets are introduced into the instrument with a nozzle of $\sim 0.12 \mathrm{~mm}$ orifice combined with an aerodynamic lens assembly tilted at $40^{\circ}$ from the horizontal plane. The droplets focused by the aerodynamic lens assembly [31] are deposited continuously on a tungsten target plate which also serves as the ion repeller of the reflectron mass spectrometer. The deposition spot is $\sim 0.5 \mathrm{~mm}$ in diameter. A $10 \mathrm{~Hz}$ pulsed $266 \mathrm{~nm} \mathrm{Nd}$ :YAG laser (New Wave Research, Polaris III) is used to desorb and ionize the sample with an incident angle of $50^{\circ}$. A quartz lens with $f=750 \mathrm{~mm}$ is used to softly focus the laser. The laser spot is approximately $0.5 \mathrm{~mm}$ in diameter. The laser energy is about $1.1 \mathrm{~mJ} /$ pulse. The ions generated by the laser are detected with a reflectron mass spectrometer characterized by a field free flight distance of $1.2 \mathrm{~m}$, an ion mirror,

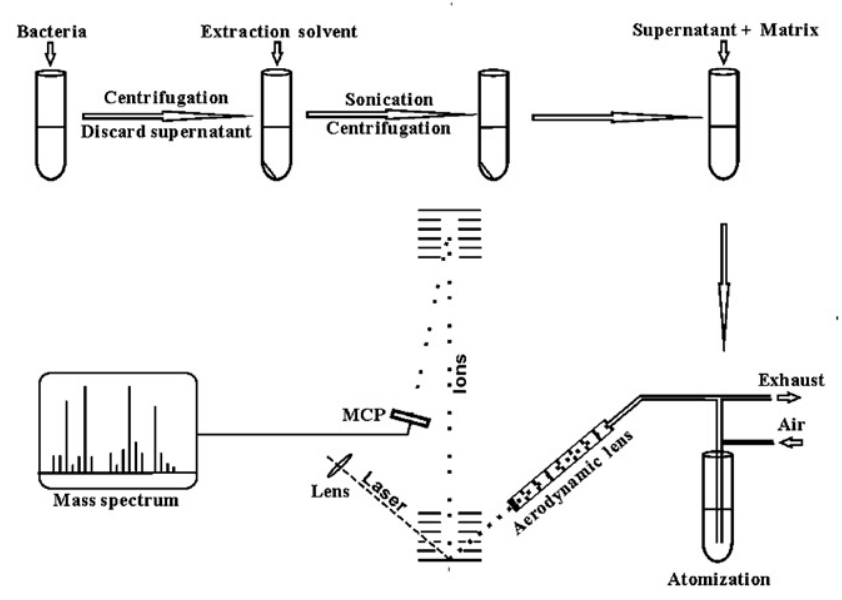

Fig. 1. Workflow of lipid analysis by online droplet-deposited MALDI mass spectrometry.

and a chevron multichannel plate detector. Each mass spectrum is acquired by averaging the ions generated from 128 laser shots. The mass spectra are calibrated by using the ions of $\alpha$-cyclodextrin, $\beta$-cyclodextrin, and polyethylene glycol (PEG) 1000 cationized by $\mathrm{Na}^{+}$. The calibration error of the mass spectra is within $\pm 0.3 \mathrm{Da}$. Unless otherwise stated, 2,4-DHB is used as the matrix, which is so far most characterized MALDI matrix in the lipid field [32]. In addition, 2,4-DHB is of higher absorption efficiency in the wavelength of $266 \mathrm{~nm}$.

\section{Results and discussion}

In the experiment, three common bacteria (E. coli, Salmonella, and $B$. subtilis) are selected as the samples. The MALDI-TOF mass spectra of the lipids extracted from the bacterial cells cultured in nutrient broth are shown in Fig. 2(A-C). E. coli and Salmonella share several mass peaks. However, the mass spectra of $B$. subtilis show significant differences from two others. The prominent mass peaks of the E. coli and Salmonella extracts range from 690 to 800 Da while those of $B$. subtilis are around $900 \mathrm{Da}$. The results reveal that the three bacterial species can be easily distinguished from their characteristic mass peak profiles. Fig. 2(D-F) shows the MALDI-TOF mass spectra of the lipids extracted from the bacterial cells cultured in LB medium. The lipid profile of $B$. subtilis cultured in LB is remarkably different from that cultured in nutrient broth. $B$. subtilis cultured in LB medium presents more mass peaks between 700 and 900 Da. By contrast, the lipid profiles of E. coli and Salmonella cultured in LB are slightly different from those cultured in nutrient broth. These results show that the culture medium can change the lipid composition of bacteria and cause the significant influence to the lipid profiles. These differences derived from culture media can be used to track the bacterial growing environment and source. Thus, the present method may have the potential for the rapid bioaerosol detection, which is a new approach compared with the single particle aerosol MALDI that has been used as a tool to achieve the online bioaerosol detection [33,34].

Considering that the formation of alkali metal ion adducts could not be completely excluded in the positive ion mode mass analysis, MALDI analyses on the extracts doped with metal halides are conducted to assist the assignment of the mass spectra obtained. Fig. 3 shows the MALDI-TOF mass spectra of Salmonella lipids from the raw extract (A) and those doped with $2 \mathrm{mM} \mathrm{NaCl}$ (B) and $\mathrm{KCl}$ (C). The MALDI-TOF mass spectra of Salmonella present remarkable changes after the extracts are doped with salts. The mass peaks at $m / z 734.3,748.3,762.4,774.5$, and 788.6 (Series 3 shown 


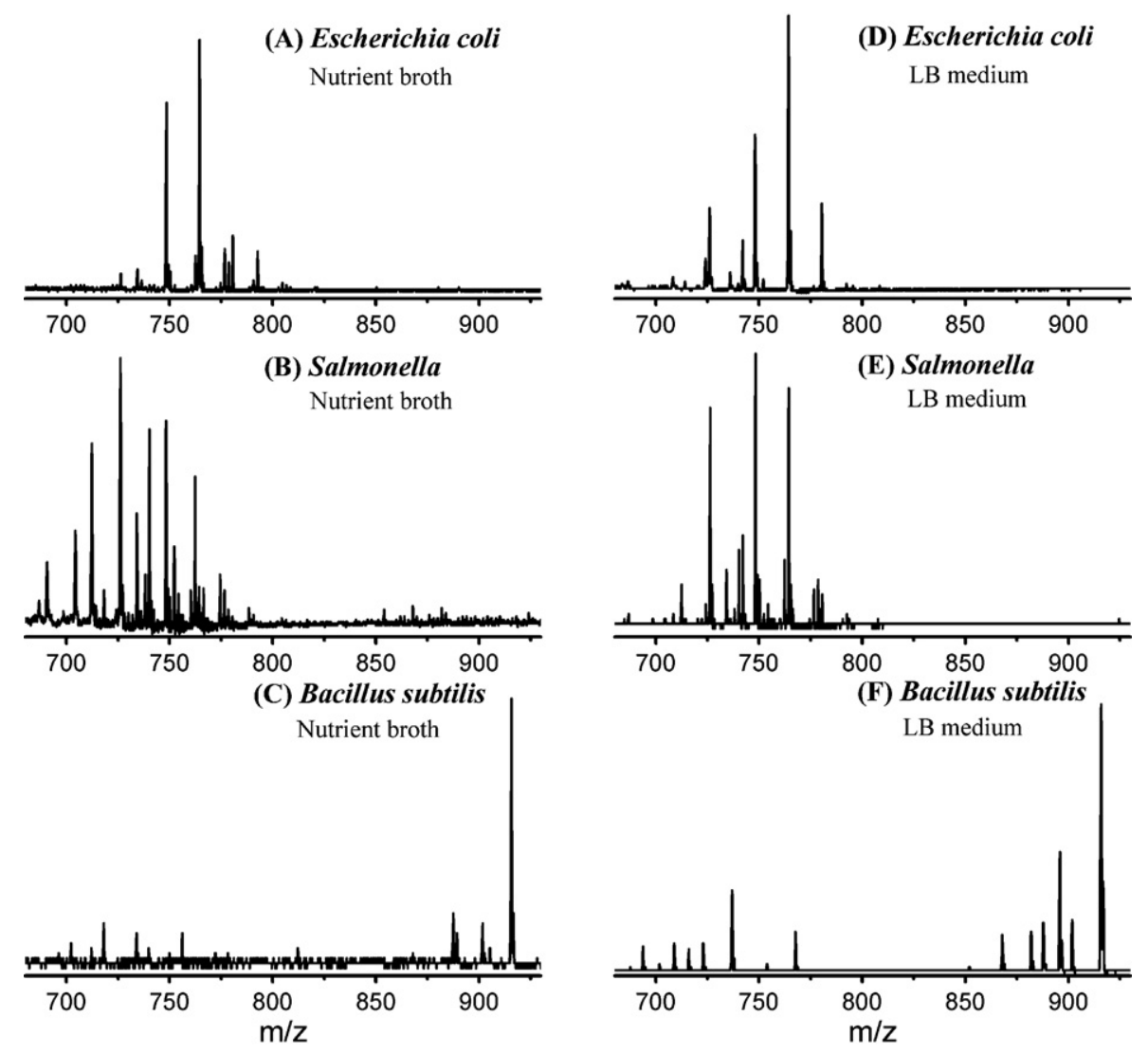

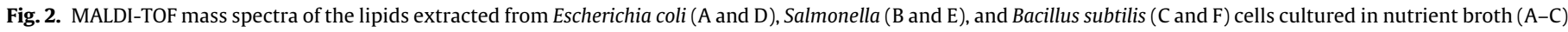
and LB (D-F) respectively.

in Fig. 3A) are enhanced when the extract is doped with $\mathrm{NaCl}$. Meanwhile, other mass peaks at $m / z$ 712.3, 726.3, 740.3, 752.3, and 766.4 (Series 2 shown in Fig. 3A) are greatly suppressed. Since the mass peaks of Series 3 are 22 Da larger than those of Series 2 , we speculate that the former are the di-sodium adduct species
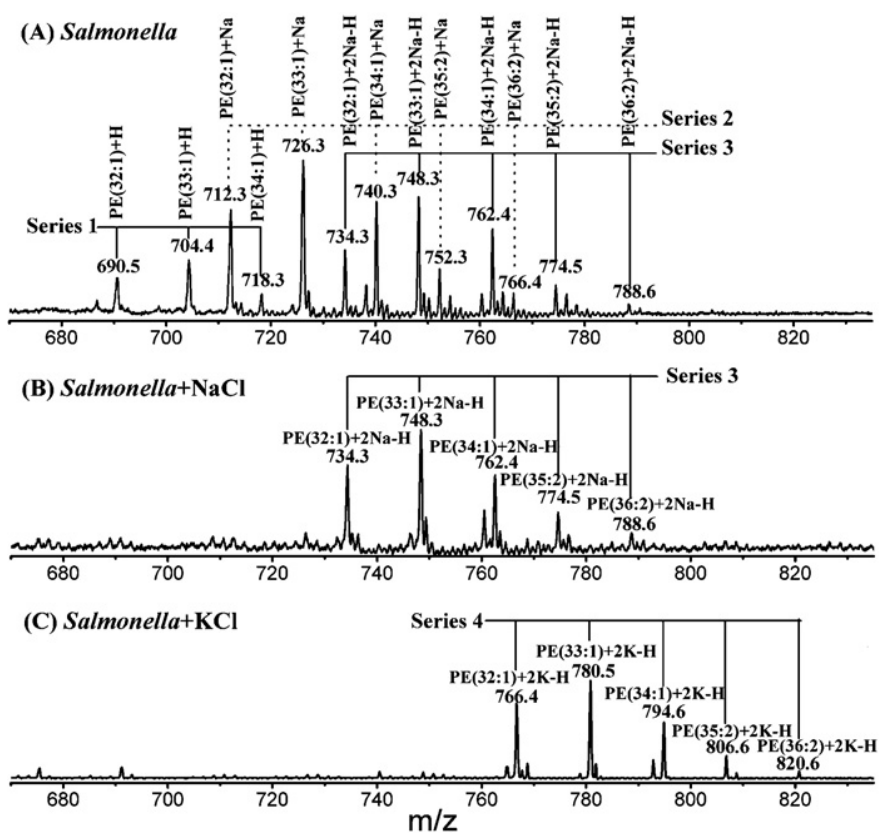

Fig. 3. MALDI-TOF mass spectra of Salmonella lipids from the raw extract (A) and those doped with $2 \mathrm{mM}$ of $\mathrm{NaCl}(\mathrm{B})$ and $\mathrm{KCl}(\mathrm{C})$. and the latter are the mono-sodium adduct species, referring to the previous study $[35,36]$. Series 1 , which is also inhibited after the extract is doped with $\mathrm{NaCl}$, is attributed to the protonated peaks for its $22 \mathrm{Da}$ shift from Series 2. Fig. 3C shows that the potassium salt can greatly enhance the mass peaks at $m / z$ 766.4, 780.5, 794.6, 806.6, and 820.6 (Series 4 shown in Fig. 3C). Taking into account of the mass shift ( $32 \mathrm{Da}$ ) between Series 4 and Series 3 , we infer that the mass peaks of Series 4 are the di-potassium adducts.

The MALDI-TOF mass spectra of E. coli and B. subtilis show similar changes when the extracts are doped with the salts. Those experimental results are not described in this paper for avoiding redundance. The assignments of the mass spectra of $E$. coli, Salmonella, and B. subtilis shown in Fig. 2 are listed in Table 1. Lipids constitute a broad group of naturally occurring molecules. According to the previous studies, phosphatidylethanolamine (PE) is a major component in bacterial lipids (up to $80 \%$ in E. coli) and phosphatidylglycerol (PG) is reportedly the second most abundant phospholipids in bacteria [37]. In the assignments, we attribute mass peaks to the most abundant lipids in bacteria. The lipid assignments are aided by using the LIPID MAPS database and the relevant previous studies.

As listed in Table 1, the protonated, sodium, potassium, disodium adduct species, and sodium-potassium adduct species are observed in the mass spectra and the di-sodium adduct species is prominent. The form of alkali metal adduct depends on the lipid species and the salts. The added salt can significantly influence the profile of the mass spectrum obtained. With the increase of the salt concentration, the intensities of the mass peaks decrease. The mass peaks almost disappear when the concentration of the salt exceeds $20 \mathrm{mM}$. The experimental results show that the MALDITOF mass spectra obtained with the present sample preparation 
Table 1

The probable assignments for the MALDI-TOF mass spectra of Escherichia coli, Salmonella, and Bacillus subtilis lipids.

\begin{tabular}{|c|c|c|c|c|c|c|}
\hline \multirow[t]{2}{*}{$m / z$} & \multicolumn{2}{|l|}{ Escherichia coli } & \multicolumn{2}{|l|}{ Salmonella } & \multicolumn{2}{|l|}{ Bacillus subtilis } \\
\hline & Nutrient broths & LB medium & Nutrient broths & LB medium & Nutrient broths & LB medium \\
\hline 690.5 & & & $\mathrm{PE}(32: 1)+\mathrm{H}$ & & & \\
\hline 704.4 & & & $P E(33: 1)+H$ & & & \\
\hline 708.6 & & $\mathrm{PE}(30: 0)+2 \mathrm{Na}-\mathrm{H}$ & & $\mathrm{PE}(30: 0)+2 \mathrm{Na}-\mathrm{H}$ & & $\mathrm{PE}(30: 0)+2 \mathrm{Na}-\mathrm{H}$ \\
\hline 712.3 & & & $\mathrm{PE}(32: 1)+\mathrm{Na}$ & $\mathrm{PE}(32: 1)+\mathrm{Na}$ & & \\
\hline 718.3 & & & $\operatorname{PE}(34: 1)+\mathrm{H}$ & & & \\
\hline 722.7 & & & & & & $\mathrm{PE}(31: 0)+2 \mathrm{Na}-\mathrm{H}$ \\
\hline 724.3 & & $\mathrm{PE}(30: 0)+\mathrm{Na}+\mathrm{K}-\mathrm{H}$ & & & & \\
\hline 726.3 & $\mathrm{PE}(33: 1)+\mathrm{Na}$ & $\mathrm{PE}(33: 1)+\mathrm{Na}$ & $\mathrm{PE}(33: 1)+\mathrm{Na}$ & $\mathrm{PE}(33: 1)+\mathrm{Na}$ & & \\
\hline 734.5 & $\mathrm{PE}(32: 1)+2 \mathrm{Na}-\mathrm{H}$ & & $\mathrm{PE}(32: 1)+2 \mathrm{Na}-\mathrm{H}$ & $\mathrm{PE}(32: 1)+2 \mathrm{Na}-\mathrm{H}$ & & \\
\hline 736.7 & & $\mathrm{PE}(32: 0)+2 \mathrm{Na}-\mathrm{H}$ & & & & $\mathrm{PE}(32: 0)+2 \mathrm{Na}-\mathrm{H}$ \\
\hline 738.3 & & & $\mathrm{PE}(34: 2)+\mathrm{Na}$ & & & \\
\hline 740.3 & & & $\mathrm{PE}(34: 1)+\mathrm{Na}$ & $\mathrm{PE}(34: 1)+\mathrm{Na}$ & & \\
\hline 742.3 & & $\operatorname{PE}(33: 1)+K$ & & & & \\
\hline 748.5 & $\mathrm{PE}(33: 1)+2 \mathrm{Na}-\mathrm{H}$ & $\mathrm{PE}(33: 1)+2 \mathrm{Na}-\mathrm{H}$ & $\mathrm{PE}(33: 1)+2 \mathrm{Na}-\mathrm{H}$ & $\mathrm{PE}(33: 1)+2 \mathrm{Na}-\mathrm{H}$ & & \\
\hline 752.3 & & & $\mathrm{PE}(35: 2)+\mathrm{Na}$ & & & \\
\hline 753.6 & & & & & & $\mathrm{PG}(31: 0)+2 \mathrm{Na}-\mathrm{H}$ \\
\hline 754.3 & & & & $\mathrm{PE}(35: 1)+\mathrm{Na}$ & & \\
\hline 762.4 & $\mathrm{PE}(34: 1)+2 \mathrm{Na}-\mathrm{H}$ & & $\mathrm{PE}(34: 1)+2 \mathrm{Na}-\mathrm{H}$ & $\mathrm{PE}(34: 1)+2 \mathrm{Na}-\mathrm{H}$ & & \\
\hline 764.4 & $\mathrm{PE}(34: 0)+2 \mathrm{Na}-\mathrm{H}$ & $\mathrm{PE}(33: 1)+\mathrm{Na}+\mathrm{K}-\mathrm{H}$ & & $\mathrm{PE}(33: 1)+\mathrm{Na}+\mathrm{K}-\mathrm{H}$ & & \\
\hline 766.4 & & & $\mathrm{PE}(36: 2)+\mathrm{Na}$ & & & \\
\hline 767.6 & & & & & & $\mathrm{PG}(32: 0)+2 \mathrm{Na}-\mathrm{H}$ \\
\hline 774.5 & & & $\mathrm{PE}(35: 2)+2 \mathrm{Na}-\mathrm{H}$ & $\mathrm{PE}(35: 2)+2 \mathrm{Na}-\mathrm{H}$ & & \\
\hline 776.5 & $\mathrm{PE}(35: 1)+2 \mathrm{Na}-\mathrm{H}$ & $\mathrm{PE}(35: 1)+2 \mathrm{Na}-\mathrm{H}$ & & $\mathrm{PE}(35: 1)+2 \mathrm{Na}-\mathrm{H}$ & & \\
\hline 780.5 & $\mathrm{PE}(34: 0)+\mathrm{Na}+\mathrm{K}-\mathrm{H}$ & $\mathrm{PE}(33: 1)+2 \mathrm{~K}-\mathrm{H}$ & & $\mathrm{PE}(34: 1)+\mathrm{Na}+\mathrm{K}-\mathrm{H}$ & & \\
\hline 788.6 & & & $\mathrm{PE}(36: 2)+2 \mathrm{Na}-\mathrm{H}$ & & & \\
\hline 792.6 & $\mathrm{PE}(35: 1)+\mathrm{Na}+\mathrm{K}-\mathrm{H}$ & $\mathrm{PE}(35: 1)+\mathrm{Na}+\mathrm{K}-\mathrm{H}$ & & & & \\
\hline 867.6 & & & & & & $\mathrm{PG}(40: 6)+2 \mathrm{Na}-\mathrm{H}$ \\
\hline 881.6 & & & & & & $\mathrm{PG}(41: 6)+2 \mathrm{Na}-\mathrm{H}$ \\
\hline 887.7 & & & & & $\operatorname{DGDG}(30: 0)+\mathrm{Na}$ & $\operatorname{DGDG}(30: 0)+\mathrm{Na}$ \\
\hline 895.6 & & & & & & $\mathrm{PG}(42: 6)+2 \mathrm{Na}-\mathrm{H}$ \\
\hline 901.7 & & & & & $\operatorname{DGDG}(31: 0)+\mathrm{Na}$ & $\operatorname{DGDG}(31: 0)+\mathrm{Na}$ \\
\hline 915.7 & & & & & $\operatorname{DGDG}(32: 0)+\mathrm{Na}$ & $\operatorname{DGDG}(32: 0)+\mathrm{Na}$ \\
\hline 931.7 & & & & & DGDG(32:0)+K & \\
\hline
\end{tabular}

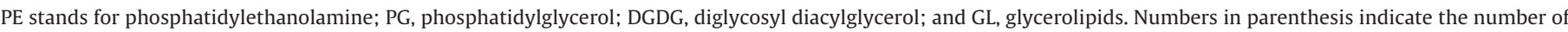
carbon atoms and double bonds in the fatty acid side chains, respectively.

protocol are mainly contributed from the sodium and potassium adducts. The culture medium influences the bacterial lipid composition in a different extent among the bacteria species.

The influence of the cell concentration on the lipid profile is investigated using the extracts with the different cell concentrations. Fig. 4 shows the mass spectra of the lipids extracted from

\section{(A) $5.8 \times 10^{4}$ cells $/ \mathrm{mL}$}

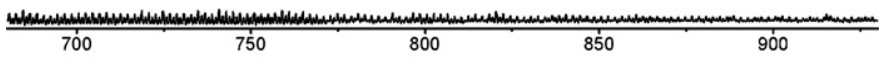

(B) $5.8 \times 10^{5}$ cells $/ \mathrm{mL}$

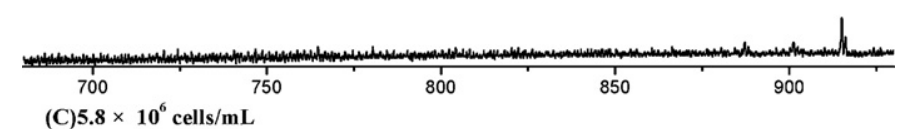

(C) $5.8 \times 10^{6}$ cells $/ \mathrm{mL}$

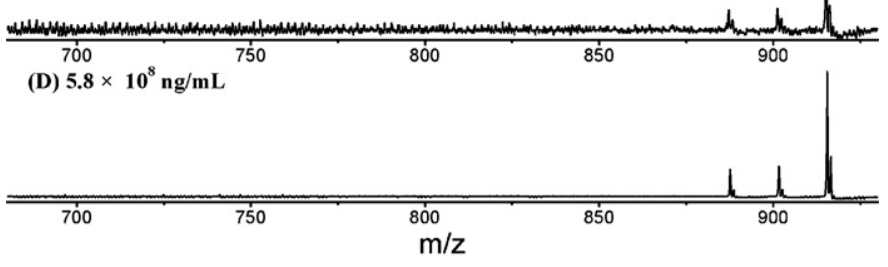

Fig. 4. MALDI-TOF mass spectra of the lipids extracted from Bacillus subtilis cells with the concentrations of $5.8 \times 10^{4}(A), 5.8 \times 10^{5}(B), 5.8 \times 10^{6}(C)$, and $5.8 \times 10^{8} / \mathrm{mL}$ (D).
B. subtilis cells with the concentrations of $5.8 \times 10^{4}, 5.8 \times 10^{5}$, $5.8 \times 10^{6}$, and $5.8 \times 10^{8} / \mathrm{mL}$. Fig. 4 reveals that the lipid profiles of $B$. subtilis with the cell concentrations from $5.8 \times 10^{6}$ to $5.8 \times 10^{8} / \mathrm{mL}$ can keep a pretty uniform shape. The lower limit of the $E$. coli and Salmonella are about one order of magnitude lower than that of $B$. subtilis.

The droplets introduced into the instrument are not completely dry and crystallized in the experiment. The evaporation time of droplets from generation to desorption is only several seconds and varied with the different solvent. So we examined the effect of solvent on the mass spectra. Fig. 5 displays the MALDI-TOF mass spectra of the lipids extracted from Salmonella cells with the solvents chloroform/methanol (A), deionized water/isopropanol (B), and isopropanol/acetonitrile (C). The profiles of the mass spectra show the dependencies on the solvents. The mass spectrum shown in Fig. 5A, which is obtained with the chloroform/methanol as the extraction solvent, mainly comprise three series of mass peaks, Series 1 (protonated mass peaks), Series 2 (sodium adduct species), and Series 3 (di-sodium adduct species). However, the mass peaks of Series 1 shown in Fig. 5(B and C) are much weaker. The di-sodium adduct species (Series 3 ) is more prominent in Fig. 5B with the extraction solvents of water and isopropanol, which may be due to the higher salt solubility of water. The sodium adduct species (Series 2) is dominant in Fig. 5C when the isopropanol/acetonitrile is used. One reason for the difference is obvious. The different solvent may contain different residual materials, especially the salt. The other reason may be that the physical property of deposited particles is different when using different solvents. The difference can influence the optimum laser energy and the desorption process. 
(A) $\mathrm{CHCl}_{3} / \mathrm{MeOH}$
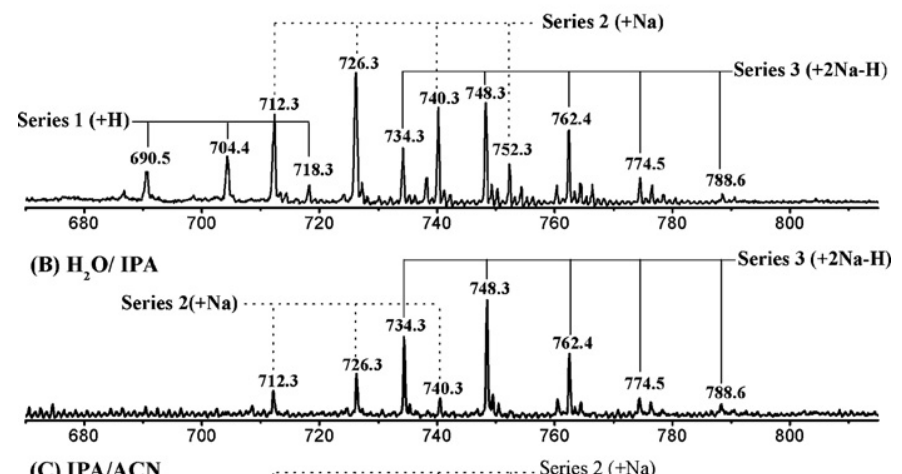

(C) IPA/ACN

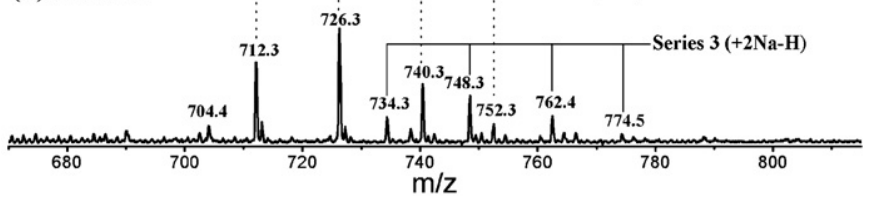

Fig. 5. MALDI-TOF mass spectra of the lipids extracted from Salmonella cells with the solvents: chloroform/methanol $\left(\mathrm{CHCl}_{3} / \mathrm{MeOH}, 2.5 \mathrm{~mL} / 2.5 \mathrm{~mL}\right)(\mathrm{A})$; deionized water/isopropanol $\left(\mathrm{H}_{2} \mathrm{O} / \mathrm{IPA}, 2.5 \mathrm{~mL} / 2.5 \mathrm{~mL}\right)(\mathrm{B})$; isopropanol/acetonitrile (IPA/ACN, $2.5 \mathrm{~mL} / 2.5 \mathrm{~mL})(\mathrm{C})$.

The experimental results show that the mass spectra obtained with chloroform/methanol as the extraction solvent present more mass peaks. The lipid profiles of the bacteria obtained in the experiment are basically consistent with previously reported profiles obtained using the traditional MALDI methods [15,36,38,39].

\section{Conclusion}

The experimental results show that the present technique can be used to rapidly obtain the lipid profiles of E. coli, Salmonella, and $B$. subtilis. Different from the reported aerosol-MALDI mass spectrometry that desorb/ionize the single particle [25], the suspended droplets containing analyte/matrix are directly deposited onto the target plate via an aerodynamic lens assembly in this experiment. Meantime, the pulse laser irradiates the deposited spot and an in situ MALDI analysis is conducted. By contrast with the aerosol MALDI, the online droplet-deposited MALDI is a bulk technique that can eliminate the fluctuation of signals from particle to particle and has a higher sensitivity of detection in theory. And compared with the traditional MALDI, the online droplet-deposited MALDI avoids the process of analyte/matrix layer preparation and achieves the continuous sampling and detection. Through a further improvement, the present technique may promisingly be used to profile lipids rapidly in laboratories and clinics for lipid studies and analyses.

\section{Acknowledgments}

This research is funded by National High Technology Research and Development Program of China (863 Program, Grant No. 2009AA06Z401) and National Natural Science Foundation of China (Grant No. 20777082).

\section{References}

[1] A. Nicolaou, G. Kokotos, Bioactive Lipids, The Oily Press, 2004.

[2] J.A. Fernandez, B. Ochoa, O. Fresnedo, M.T. Giralt, R. Rodriguez-Puertas, Matrixassisted laser desorption ionization imaging mass spectrometry in lipidomics, Analytical and Bioanalytical Chemistry 401 (2011) 29-51.

[3] T. Shimizu, Lipid mediators in health and disease: enzymes and receptors as therapeutic targets for the regulation of immunity and inflammation, Annual Review of Pharmacology and Toxicology 49 (2009) 123-150.
[4] A.D. Watson, Lipidomics: a global approach to lipid analysis in biological systems, The Journal of Lipid Research 47 (2006) 2101-2111.

[5] C. Wolf, P.J. Quinn, Lipidomics: practical aspects and applications, Progress in Lipid Research 47 (2008) 15-36.

[6] R.M. Adibhatla, J.F. Hatcher, Lipid oxidation and peroxidation in CNS health and disease: from molecular mechanisms to therapeutic opportunities, Antioxidants and Redox Signalling 12 (2010) 125-169.

[7] X.L. Han, R.W. Gross, Global analyses of cellular lipidomes directly from crude extracts of biological samples by ESI mass spectrometry: a bridge to lipidomics, The Journal of Lipid Research 44 (2003) 1071-1079.

[8] N. Zehethofer, D.M. Pinto, Recent developments in tandem mass spectrometry for lipidomic analysis, Analytica Chimica Acta 627 (2008) 62-70.

[9] A. Fox, Mass spectrometry for species or strain identification after culture or without culture: past, present, and future, Journal of Clinical Microbiology 44 (2006) 2677-2680

[10] S. Deluca, E.W. Sarver, P.D. Harrington, K.J. Voorhees, Direct analysis of bacterial fatty-acids by Curie-point pyrolysis tandem mass-spectrometry, Analytical Chemistry 62 (1990) 1465-1472.

[11] F. Basile, K.J. Voorhees, T.L. Hadfield, Microorganism Gram-type differentiation based on pyrolysis mass-spectrometry of bacterial fatty-acid methyl-ester extracts, Applied and Environment Microbiology 61 (1995) 1534-1539.

[12] A.A. Gharaibeh, K.J. Voorhees, Characterization of lipid fatty acids in wholecell microorganisms using in situ supercritical fluid derivatization/extraction and gas chromatography mass spectrometry, Analytical Chemistry 68 (1996) 2805-2810.

[13] S.C. Ingham, M.M. Lang, B.H. Ingham, Differentiation of Enterococcus spp. by cell membrane fatty acid methyl ester profiling, biotyping and ribotyping, Letters in Applied Microbiology 33 (2001) 65-70.

[14] P.B.W. Smith, A.P. Snyder, C.S. Harden, Characterization of bacterial phospholipids by electrospray-ionization tandem mass-spectrometry, Analytical Chemistry 67 (1995) 1824-1830.

[15] Y. Ishida, A.J. Madonna, J.C. Rees, M.A. Meetani, K.J. Voorhees, Rapid analysis of intact phospholipids from whole bacterial cells by matrix-assisted laser desorption/ionization mass spectrometry combined with on-probe sample pretreatment, Rapid Communications in Mass Spectrometry 16 (2002) 1877-1882.

[16] J.J. Jones, M.J. Stump, R.C. Fleming, J.O. Lay, C.L. Wilkins, Strategies and data analysis techniques for lipid and phospholipid chemistry elucidation by intact cell MALDI-FTMS, Journal of the American Society for Mass Spectrometry 15 (2004) 1665-1674.

[17] B. Fuchs, J. Schiller, Application of MALDI-TOF mass spectrometry in lipidomics, European Journal of Lipid Science and Technology 111 (2009) 83-98.

[18] L. Li, A.P.L. Wang, L.D. Coulson, Continuous-flow matrix-assisted laser desorption ionization mass-spectrometry, Analytical Chemistry 65 (1993) 493-495.

[19] Q. Zhan, A. Gusev, D.M. Hercules, A novel interface for on-line coupling of liquid capillary chromatography with matrix-assisted laser desorption/ionization detection, Rapid Communications in Mass Spectrometry 13 (1999) 2278-2283.

[20] J. Preisler, F. Foret, B.L. Karger, On-line MALDI-TOF MS using a continuous vacuum deposition interface, Analytical Chemistry 70 (1998) 5278-5287.

[21] H. Orsnes, T. Graf, H. Degn, K.K. Murray, A rotating ball inlet for on-line MALDI mass spectrometry, Analytical Chemistry 72 (2000) 251-254.

[22] X. Zhang, D.A. Narcisse, K.K. Murray, On-line single droplet deposition for MALDI mass spectrometry, Journal of the American Society for Mass Spectrometry 15 (2004) 1471-1477.

[23] K.K. Murray, Coupling matrix-assisted laser desorption/ionization to liquid separations, Mass Spectrometry Reviews 16 (1997) 283-299.

[24] K.K. Murray, D.H. Russell, Liquid sample introduction for matrix-assisted laser desorption ionization, Analytical Chemistry 65 (1993) 2534-2537.

[25] K.K. Murray, T.M. Lewis, M.D. Beeson, D.H. Russell, Aerosol matrix-assisted laser desorption 275 ionization for liquid chromatography/time-of-flight mass spectrometry, Analytical Chemistry 66 (1994) 1601-1609.

[26] B.A. Mansoori, M.V. Johnston, A.S. Wexler, Matrix-assisted laser desorption/ionization of size- and composition selected aerosol particles, Analytical Chemistry 68 (1996) 3595-3601.

[27] X. Fei, G. Wei, K.K. Murray, Aerosol MALDI with a reflectron time-of-flight mass spectrometer, Analytical Chemistry 68 (1996) 1143-1147.

[28] M.A. Stowers, A.L. van Wuijckhuijse, J.C.M. Marijnissen, B. Scarlett, B.L.M. van Baar, C.E. Kientz, Application of matrix-assisted laser desorption/ionization to on-line aerosol time-of-flight mass spectrometry, Rapid Communications in Mass Spectrometry 14 (2000) 829-833.

[29] W.A. Harris, P.T.A. Reilly, W.B. Whitten, Aerosol MALDI of peptides and proteins in an ion trap mass spectrometer: trapping, resolution and signal-to-noise, International Journal of Mass Spectrometry 258 (2006) 113-119.

[30] J. Shu, J. Meng, X. Shu, Y. Zhang, S. Gao, B. Yang, J. Gan, Online MALDI-TOF MS using an aerodynamic lens assembly as a direct deposition interface, Analytical Chemistry 82 (2010) 5906-5909.

[31] X. Zhang, K.A. Smith, D.R. Worsnop, J. Jimenez, J.T. Jayne, C.E. Kolb, A numerical characterization of particle beam collimation by an aerodynamic lens-nozzle system: Part I. An individual lens or nozzle, Aerosol Science and Technology 36 (2002) 617-631.

[32] J. Schiller, J. Arnhold, S. Benard, M. Muller, S. Reichl, K. Arnold, Lipid analysis by matrix-assisted laser desorption and ionization mass spectrometry: a methodological approach, Analytical Biochemistry 267 (1999) 46-56.

[33] S.C. Russell, Microorganism characterization by single particle mass spectrometry, Mass Spectrometry Reviews 28 (2009) 376-387. 
[34] W.A. Kleefsman, M.A. Stowers, PJ.T. Verheijen, J.C.M. Marijnissen, Single particle mass spectrometry - bioaerosol analysis by MALDI MS, KONA: Powder and Particle Journal 26 (2008) 205-214.

[35] D.N. Heller, R.J. Cotter, C. Fenselau, Profiling of bacteria by fast-atombombardment mass-spectrometry, Analytical Chemistry 59(1987) 2806-2809.

[36] J. Gidden, J. Denson, R. Liyanage, D.M. Ivey, J.O. Lay, Lipid compositions in Escherichia coli and Bacillus subtilis during growth as determined by MALDI-TOF and TOF/TOF mass spectrometry, International Journal of Mass Spectrometry 283 (2009) 178-184.
[37] W. Dowhan, Molecular basis for membrane phospholipid diversity: why are there so many lipids? Annual Review of Biochemistry 66 (1997) 199-232.

[38] C.D. Calvano, C.G.Zambonin, F. Palmisano, Lipid fingerprinting of Gram-positive lactobacilli by intact cells - matrix-assisted laser desorption/ionization mass spectrometry using a proton sponge based matrix, Rapid Communications in Mass Spectrometry 25 (2011) 1757-1764.

[39] J.J. Jones, M.J. Stump, R.C. Fleming, J.O. Lay, C.L. Wilkins, Investigation of MALDITOF and FT-MS techniques for analysis of Escherichia coli whole cells, Analytical Chemistry 75 (2003) 1340-1347. 